\title{
Norovirus Surrogate Survival on Spinach During Preharvest Growth
}

\author{
Kirsten A. Hirneisen and Kalmia E. Kniel
}

Department of Animal and Food Sciences, University of Delaware, Newark 19716.

Accepted for publication 16 January 2013.

\begin{abstract}
Hirneisen, K. A., and Kniel, K. E. 2013. Norovirus surrogate survival on spinach during preharvest growth. Phytopathology 103:389-394.

Produce can become contaminated with human viral pathogens in the field through soil, feces, or water used for irrigation; through application of manure, biosolids, pesticides, and fertilizers; and through dust, insects, and animals. The objective of this study was to assess the survival and stability of human noroviruses and norovirus surrogates (Murine norovirus $[\mathrm{MNV}]$ and Tulane virus $[\mathrm{TV}])$ on foliar surfaces of spinach plants in preharvest growth conditions. Spinach plants were housed in a biocontrol chamber at optimal conditions for up to 7 days and infectivity was determined by plaque assay. Virus inoculation location had the largest im-

decimal reduction time (D values) than viruses present on abaxial leaf surfaces. Under certain conditions, spinach type impacted virus survival, with greater $\mathrm{D}$ values observed from survival on semi-savoy spinach leaves. Additional UVA and UVB exposure to mimic sunlight affected virus survival on adaxial surfaces for both semi-savoy and smooth spinach plants for both viruses. Human GII norovirus inoculated onto semi-savoy spinach had an average D value that was not statistically significant from MNV and TV, suggesting that these surrogates may have similar survival on spinach leaves compared with human noroviruses. An understanding of the behavior of enteric viruses on spinach leaves can be used to enhance growers' guidelines and for risk assessment with certain growing conditions.
\end{abstract} pact on virus survival as viruses present on adaxial leaf surfaces had lower
Produce can become contaminated with human viral pathogens in the field through soil, feces, or water used for irrigation; through application of manure, biosolids, pesticides, and fertilizers; through dust, insects, and animals; or during postharvest (harvesting equipment, transport containers, animals, insects, and dust) and by foodhandlers in food service establishments (4). The 2006 outbreak of Escherichia coli O157:H7-contaminated spinach that resulted in 205 confirmed cases and 3 deaths (CDC 2006 [6]) served as a catalyst for the development of more effective measures (Matthews 2009 [23]) and research efforts to ensure the safety of leafy greens. Although the Leafy Greens Marketing Agreement guidelines and Good Agricultural Practice Guidelines outline practices intended to reduce the risk of leafy green contamination, outbreaks still occur and human pathogens can be detected on these commodities. A recent survey testing packaged leafy greens in Canada, Belgium, and France for human noroviruses confirmed the presence of human norovirus RNA as detected by real-time reverse-transcription polymerase chain reaction (RT-PCR) on 28 to $50 \%$ of samples, depending on the country of sampling (2). Although these sequences were not associated with documented outbreaks, the results suggest that packaged produce is a source for human noroviruses (10). Virus survival is important to consider when evaluating potential risk of illness from a contamination event in the environment. Due to increasing outbreaks of foodborne pathogens associated with produce items, there is an increased desire to understand the interaction of these non-plant pathogens with the plant.

Human noroviruses are the leading cause of foodborne illness, causing $\approx 58 \%$ of foodborne illnesses (24). The low infectious dose of noroviruses, the estimated average being 18 virus particles (29), means that even a small amount of contamination has the potential to cause illness. Although typically mild and self-limiting, norovirus infections may have more severe outcomes among

Corresponding author K. E. Kniel; E-mail address: kniel@udel.edu

http://dx.doi.org/10.1094/PHYTO-09-12-0231-FI

(c) 2013 The American Phytopathological Society elderly and immunocompromised patients (26). Noroviruses are genetically diverse and are classified into five genogroups, which are composed of multiple genotypes (34). GI, GII, and GIV strains infect humans, with GII noroviruses being the most prevalent and genetically diverse (34). Currently, an animal or cell culture model for human noroviruses does not exist; therefore, a surrogate such as Murine norovirus (MNV) is used to predict norovirus behavior in survival and persistence studies. MNV was the first norovirus to be propagated in cell culture and shares similar genetic and structural features with human norovirus (32). Tulane virus (TV) is a more recently discovered Calicivirus sp. isolated from the stools of rhesus macaques (Macaca mulatta) and is a Calicivirus sp. with significant genetic diversity, representing a new genus, Recovirus (12). Although TV is not as genetically related as MNV, it may be a useful surrogate because of its ability to bind to Histo-blood group antigens (HBGAs) as host cell receptors similarly to human norovirus (12). Recently, we compared the survival of these two norovirus surrogates in varying $\mathrm{pH}$ solutions, chlorine, temperatures, and survival in tap water for 30 days (16). Overall, MNV appeared to be a more stable surrogate because it persisted at lower $\mathrm{pHs}$ and in tap water for up to 30 days at $4^{\circ} \mathrm{C}$, whereas TV was not as stable. TV was used recently in a study assessing internalization into Romaine lettuce, whereby TV was observed to behave similarly to human noroviruses (7).

The objective of this study was to assess norovirus survival on spinach leaves and leaf surfaces in preharvest growth conditions. The survival of human GII noroviruses and the potential surrogates, MNV and TV, was assessed under optimal growing conditions on semi-savoy and savoy spinach leaf type, on adaxial and abaxial leaf surfaces, and after exposure to UVA and UVB (UVA/UVB) to mimic sunlight.

\section{MATERIALS AND METHODS}

Viruses. TV (generously provided by Dr. Xi Jiang, University of Cincinnati College of Medicine, Cincinnati, $\mathrm{OH}$ ) was propagated in LLC-MK2 cells cultured in Medium 199 (M199) sup- 
plemented with $10 \%$ fetal bovine serum (FBS), 1\% penicillin/ streptomycin, and 1\% sodium bicarbonate. MNV-1 (generously provided H. Virgin, Washington University, St. Louis) was propagated in the RAW 264.7 cell line cultured in Dulbecco's modified Eagle's medium (DMEM) (Gibco-Invitrogen, Carlsbad, CA) supplemented with $10 \%$ FBS, $1 \%$ penicillin/streptomycin, $1 \%$ sodium bicarbonate, and $1 \%$ glutamate.

Human GII noroviruses were isolated from fecal samples (generously provided by Megan Davis, South Carolina Department of Health and Environmental Control). Norovirus was extracted from stool samples following a protocol similar to that of Straub et al. (26). Stool samples were suspended in phosphatebuffered saline (PBS) $(0.01 \mathrm{M})$ to obtain a 10 to $20 \%$ stool suspension. The suspension was vortexed for $60 \mathrm{~s}$ and centrifuged at $1,000 \times g$. Norovirus was purified by a polyethylene glycol (PEG) precipitation as described by Lewis and Metcalf (22). Briefly, viral suspensions were added to PEG 8000 (Fisher Scientific, Waltham, MA) for a final concentration of $8 \%$ (wt/vol) and stirred for $2 \mathrm{~h}$ at $4^{\circ} \mathrm{C}$ before centrifugation at $10,000 \times g$ for $20 \mathrm{~min}$. PEG supernatant was discarded and the viral pellet was resuspended in $0.15 \mathrm{M} \mathrm{Na}_{2} \mathrm{HPO}_{4}$ (pH 9.0) and shaken for $20 \mathrm{~min}$ at $250 \mathrm{rpm}$ before centrifugation at $10,000 \times g$ for $30 \mathrm{~min}$. The suspension was processed through at $0.22-\mu \mathrm{m}$ filter to remove bacterial contamination before storage at $-80^{\circ} \mathrm{C}$.

Spinach. Spinach (Spinacia oleracea) seed, both Spargo (F1) semi-savoyed leaf and 7-Green (F1) smooth leaf, were purchased from Johnny's Selected Seeds (Winslow, ME). Seed were germinated in ReadyEarth soilless medium (Sun Gro Horticulture Company, Bellevue, WA) under misting conditions for 10 days in the misting room of the Fisher Greenhouse at the University of Delaware. After germination, seedlings were transplanted to ProMix soilless medium (Premier Tech Horticulture Inc., Quakertown, PA) in pots (5 in.) and moved to a biocontrol chamber. Plants were grown to maturity (37 days) at $18^{\circ} \mathrm{C}$ and $65 \%$ humidity with a light intensity of $150 \mu \mathrm{E} / \mathrm{m}^{2} / \mathrm{s}$ for a photoperiod of $15 \mathrm{~h}$ and a dark period of $9 \mathrm{~h}$ by a high-intensity discharge light. All spinach plants were watered every other day as needed.

Virus inoculation of spinach and plant analysis. For virus inoculation of the whole foliar surfaces of the spinach plant, plants were transferred to a biosafety hood and spinach plant leaves were sprayed with virus (MNV, TV, and NoV G2) suspended in Hank's Balanced Salt Solution (HBSS) $\left(0.014 \% \mathrm{CaCl}_{2}\right.$, $0.04 \% \mathrm{KCl}, 0.001 \% \mathrm{MgSO}_{4} \cdot 7 \mathrm{H}_{2} \mathrm{O}, 0.006 \% \mathrm{KH}_{2} \mathrm{PO}_{4}, 0.8 \%$ $\mathrm{NaCl}$, and $\left.0.005 \% \mathrm{Na}_{2} \mathrm{HPO}_{4}\right)\left(10^{6} \log\right.$ plaque forming units (PFU)/ml MNV; $10^{5} \log$ PFU/ml TV; $10^{6}$ RT-quantitative [q]PCR units per milliliter of NoV G2) using a hand-held airbrush (model 200; Badger Air Brush Company, Franklin Park, IL) connected to an air compressor (model 180-10; Badger Air Brush Co). This method, as described by Ingram et al. (18), deposited a fine mist of each virus onto the entire above soil surfaces of the spinach plant, including the foliar surfaces and the stem, adaxial, and abaxial surfaces of the leaves. Plants were sprayed for $\approx 20 \mathrm{~s}$ each, resulting in the application of $\approx 10^{5} \log$ PFU of virus solution on the foliar surfaces of each spinach plant. For spinach plants that were inoculated on adaxial or abaxial surfaces only, MNV and TV $\left(10^{6} \log\right.$ PFU of MNV and TV) were painted with a paintbrush onto the leaf surface and allowed to dry. Spinach plants were kept at optimal conditions in the greenhouse biocontrol chamber for up to 7 days for sampling. Plants were removed for sampling on days $0,1,3,5$, and 7 . On each sampling day, spinach leaves were removed from plants and placed in a sterile stomacher bag. Leaves were stomached for $2 \mathrm{~min}$ in $10 \mathrm{ml}$ of HBSS using an electric Stomacher, whereby spinach plants are massaged by paddles in a manner mimicking the human stomach. After stomaching, supernatant was removed and used for plaque assay analysis. Controls using uninoculated spinach were used to assess cytotoxic effects on cell culture during plaque assay. In all, $\approx 1 \log$ PFU of MNV and TV titer was lost in the recovery process.
UVA/UVB exposure to spinach plants. To assess the role of UVA/UVB on virus survival on spinach plants, leaves were exposed to UVA/UVB using a UVA/UVB reptile lamp for $10 \mathrm{~h} /$ day over a 7-day period. The UVA/UVB lamp held a 100-W bulb designed to mimic sunlight, with UVA/UVB output of a total of $285 \mu \mathrm{E}$ units $/ \mathrm{m}^{2} / \mathrm{s}$ in the chamber with the additional light. The light was suspended in the chamber directly over the plants. Plants were grown at $18^{\circ} \mathrm{C}, 65 \%$ humidity and a light intensity of an additional $150 \mu \mathrm{E}$ units $/ \mathrm{m}^{2} / \mathrm{s}$ for a photoperiod of $15 \mathrm{~h}$ and dark period of $9 \mathrm{~h}$ in addition to the UVA/UVB light. Light intensity was detected with a UV AB digital light meter (General Inc., Taiwan). All spinach plants were watered every other day as needed.

Virus quantification. MNV infectivity was determined by plaque assay, as described by Hirneisen et al. (17). In brief, samples were serially diluted and inoculated onto confluent monolayers of RAW 264.7 cells grown in 12-well plates. After overnight incubation at $37^{\circ} \mathrm{C}$, the inoculum was aspirated and the cells were overlaid with $1 \mathrm{ml}$ of $1.5 \%$ agarose in DMEM. After 1 day of additional incubation at $37^{\circ} \mathrm{C}$, the plaques were visualized by staining with neutral red for 6 to $8 \mathrm{~h}$. TV infectivity was determined by plaque assay adapted from Farkas et al. (11). Serially diluted samples were inoculated onto confluent monolayers of LLC-MK2 cells grown in 6-well plates overnight at $37^{\circ} \mathrm{C}$. Samples were allowed to incubate overnight $(18 \mathrm{~h})$ at $37^{\circ} \mathrm{C}$ and inoculum was removed followed by a 2 -ml overlay of $1.5 \%$ Sea Plaque agarose (Lonza, Rockland, ME) in M199. Plates were allowed to incubate for 5 days at $37^{\circ} \mathrm{C}$ and plaques were visualized by staining with neutral red for 6 to $8 \mathrm{~h}$. The limit of detection for the viral plaque assays was 100 virus particles.

The persistence of the norovirus genome was detected on spinach leaves by two-step RT-PCR and virus quantity was determined by comparison with a standard curve. The standard curve reactions had known dilutions of virus and were prepared in spinach homogenate. Human GII norovirus was added to $1 \mathrm{ml}$ of spinach homogenate, made by stomaching $1 \mathrm{~g}$ of plant in $10 \mathrm{ml}$ of sterile HBSS to create the $10^{-1}$ dilution. The $10^{-1}$ virus dilution was serially diluted to $10^{-6}$. Viral RNA was extracted using the QIAamp Viral RNA Mini Kit (Qiagen, CA) following the manufacturer's instructions; total RNA was eluted with $60 \mu \mathrm{l}$ of RNase-free water and stored at $-80^{\circ} \mathrm{C}$ until use. The RT step was conducted with Omniscript RT Kit (Qiagen), and the qPCR was performed with a QuantiTect SYBR Green PCR Kit (Qiagen) by using an ABI 7900HT system (Applied Biosystems, Foster City, CA). The RT-PCR was performed in $20-\mu$ l volumes containing $2.0 \mu \mathrm{l}$ of $10 \times$ buffer, $2.0 \mu \mathrm{l}$ of $\mathrm{dNTP}, 1.0 \mu \mathrm{l}$ of each primer, $0.25 \mu \mathrm{l}$ of RNase inhibitor $(20 \mathrm{U} / \mu \mathrm{l}), 1 \mu \mathrm{l}$ of RT, $9.75 \mu \mathrm{l}$ of RNase-free $\mathrm{H}_{2} \mathrm{O}$, and $2 \mu \mathrm{l}$ of RNA and amplified at $37^{\circ} \mathrm{C}$ for $60 \mathrm{~min}$ to create cDNA. qPCR was performed in 20- $\mu$ l volumes containing $10 \mu \mathrm{l}$ of $2 \times$ SYBR Green Mix, $1.2 \mu \mathrm{l}$ of each primer, $2 \mu \mathrm{l}$ of cDNA, and $5.6 \mu \mathrm{H}_{2} \mathrm{O}$. The amplification cycle was $95^{\circ} \mathrm{C}$ for $15 \mathrm{~min} ; 40$ cycles of $94^{\circ} \mathrm{C} 15 \mathrm{~s}, 60^{\circ} \mathrm{C}$ for $30 \mathrm{~s}$, and $72^{\circ} \mathrm{C} 30 \mathrm{~s}$; followed by a dissociation step of $95^{\circ} \mathrm{C} 15 \mathrm{~s}, 60^{\circ} \mathrm{C} 15 \mathrm{~s}$, and $95^{\circ} \mathrm{C} 15 \mathrm{~s}$. Every sample was carried out in duplicate for the qPCR step. The cycle threshold was defined as the PCR cycle for which the fluorescence intensity exceeded the threshold value set at 0.5 . Primers for human GII norovirus were designed by Primer3 and targeted the VP1 region (VP1-FP3, 5'-TGGGTGCTCCCAAGTTATTC-3' and VP1-RP3, 5'-CTGGAGCTGCCTCTTGGTAG-3') to produce a product of $196 \mathrm{bp}$. The specificity of the amplification reaction was confirmed by the formation of a melting curve with a single peak, indicating the formation of a single PCR product. For additional confirmation of specific amplification, the qPCR reaction was run on an agarose gel. Two positive controls of pure human GII norovirus suspended in HBSS or spinach homogenate, and two negative controls consisting of the spinach without virus and a process control which contained PBS in place of the template RNA were used to assess the efficacy of the RT-qPCR reactions. 
Cryo-scanning electron microscopy of spinach leaves. Cryoscanning electron microscopy (cryo-SEM) of spinach leaves without virus inoculation was performed on a Hitachi 4700 FE-SEM with spinach cryo-frozen in a Gatan Alto 2500 cryo-system. Images were taken of semi-savoy and smooth leaves on both the adaxial and abaxial leaf surfaces. Images represent one plant sample of semi-savoy spinach and one plant sample of smooth spinach, with 16 total views made from each preparation.

Statistical analysis. Survival experiments were performed in duplicate for each growing condition on different days. For each biological replicate, two technical replicates were assessed for viral infectivity via plaque assay $(n=4)$. Linear regression analysis was performed for virus survival over time and virus survival was represented as the decimal reduction time (D values), which was calculated by dividing the slope of the linear regression line by -1 . Results are reported as means and standard deviations of the means. Statistical analysis was performed with JMP software (SAS Institute, Inc., Cary, NC). Analysis of variance (ANOVA) and Student's $t$ test were performed to compare virus type, spinach type, inoculation location, and UVA/UVB exposure on virus survival on spinach plants. Results with $P$ values $\leq 0.05$ were considered significant.

\section{RESULTS}

MNV and TV survival on spinach under unaltered conditions. MNV and TV survival on semi-savoy and smooth spinach leaves when inoculated on the entire foliar surface of the spinach plant, including the stem (from here on referred to as the "whole plant"), as well as the adaxial and abaxial leaf surfaces, is shown in Table 1 as $D$ values. $D$ values representing the time needed for a 1-log reduction in titer of $\mathrm{MNV}$ and $\mathrm{TV}$ on the whole plant and adaxial and abaxial leaves of semi-savoy and smooth spinach over 7 days is shown in Table 1. MNV and TV persisted on whole spinach plants on both semi-savoy and smooth spinach plants for the 7 days of the study. Overall, both MNV and TV survival was significantly $(P \leq 0.05$, ANOVA) impacted by virus location (whole plant and adaxial or abaxial leaf surfaces). Overall, MNV and TV inoculated on adaxial leaves did not persist as long as on abaxial leaves and whole spinach plants. No statistical significance $(P>0.05)$ was observed between MNV and TV D values. Spinach type had an impact on virus survival because a statistical significance was observed between survival on semi-savoy and smooth spinach plants under certain conditions (Table 1); whereby D values were significantly greater on semi-savoy leaves than smooth leaves. Human GII norovirus persisted on whole semi-savoy spinach leaves for 7 days, as detected by RT-qPCR (Fig. 1). The D value of norovirus on the whole plant was $5.21 \pm$ 1.50. In comparison with MNV and TV D values as determined from RT-qPCR, human norovirus survival was not significantly different $(P>0.05)$ than MNV and TV survival on whole semisavoy spinach plants at optimal conditions (data not shown).

Virus survival on spinach with UVA/UVB exposure. To assess the role of sunlight, spinach plants were exposed to UVA/UVB using a lamp to mimic sunlight for $10 \mathrm{~h} /$ day for 7 days in a controlled environment. Overall, through ANOVA analysis, UVA/UVB exposure was not observed to have a significant impact on virus survival; however, Student's $t$ test statistical analysis indicated that there was a statistical significance between additional UVA/UVB exposure and unaltered conditions on adaxial leaf surfaces for MNV and TV on semi-savoy leaves and for MNV on smooth leaves (Table 1).

SEM images. Differences in the epidermis of the spinach leaves for both semi-savoy and smooth cultivars as well as the adaxial and abaxial surfaces were visualized using cryo-SEM (Fig. 2). Epidermal cells of the abaxial semi-savoy leaves had steep incline in the walls between the cells (Fig. 2A) that was not observed between the epidermal cells of the adaxial leaf (Fig. 2B). Additionally, more stomata were observed on the abaxial leaf epidermis (Fig. 2A) as compared with adaxial surfaces (Fig. 2B). No difference was observed between abaxial and adaxial leaf surfaces in smooth spinach leaves (data not shown).

\section{DISCUSSION}

As greater numbers of foodborne outbreaks are associated with produce contamination in the field, it is important to understand the potential routes of contamination and survival of these pathogens. Researchers are taking greater interest in understanding plant-human pathogen interactions, in terms of enteric pathogen

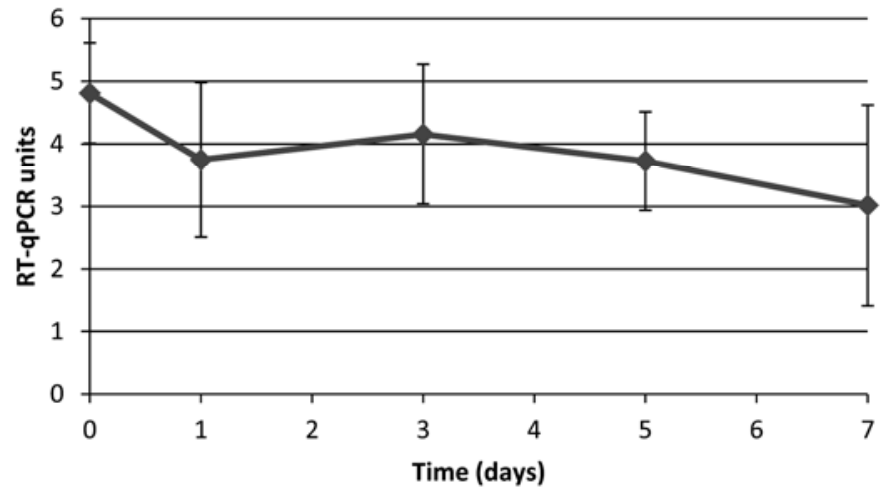

Fig. 1. Human GII norovirus survival on semi-savoy spinach plants over 14 days as detected by reverse-transcription quantitative polymerase chain reaction.

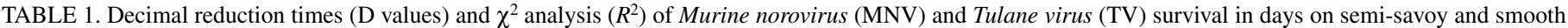

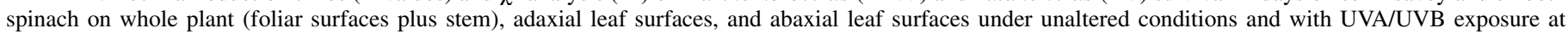
$10 \mathrm{~h} /$ day $^{\mathrm{z}}$

\begin{tabular}{|c|c|c|c|c|c|c|c|c|}
\hline \multirow[b]{3}{*}{ Spinach } & \multicolumn{4}{|c|}{ Unaltered conditions } & \multicolumn{4}{|c|}{ Additional UV } \\
\hline & \multicolumn{2}{|c|}{ Semi-savoy spinach } & \multicolumn{2}{|c|}{ Smooth spinach } & \multicolumn{2}{|c|}{ Semi-savoy spinach } & \multicolumn{2}{|c|}{ Smooth spinach } \\
\hline & MNV & $\mathrm{TV}$ & $\mathrm{MNV}$ & TV & $\mathrm{MNV}$ & TV & MNV & TV \\
\hline Whole & $\begin{array}{c}4.84 \pm 1.76^{\mathrm{A}, \mathrm{a}, 1, \mathrm{X}} \\
R^{2}=0.87\end{array}$ & $\begin{array}{c}5.73 \pm 2.41^{\mathrm{A}, \mathrm{a}, 1, \mathrm{X}} \\
R^{2}=0.92\end{array}$ & $\begin{array}{c}2.50 \pm 0.86^{\mathrm{A}, \mathrm{a}, 1, \mathrm{X}} \\
R^{2}=0.84\end{array}$ & $\begin{array}{c}3.07 \pm 1.94^{\mathrm{A}, \mathrm{a}, 1, \mathrm{X}} \\
R^{2}=0.96\end{array}$ & $\begin{array}{c}3.52 \pm 0.52^{\mathrm{A}, \mathrm{a}, 1, \mathrm{X}} \\
R^{2}=0.78\end{array}$ & $\begin{array}{c}3.78 \pm 1.70^{\mathrm{A}, \mathrm{a}, 1, \mathrm{X}} \\
R^{2}=0.80\end{array}$ & $\begin{array}{c}1.40 \pm 0.14^{\mathrm{A}, \mathrm{b}, 2, \mathrm{Y}} \\
R^{2}=0.95\end{array}$ & $\begin{array}{c}1.51 \pm 0.10^{\mathrm{A}, \mathrm{b}, 2, \mathrm{X}} \\
R^{2}=0.92\end{array}$ \\
\hline Adaxial & $\begin{array}{c}2.55 \pm 0.50^{\mathrm{A}, \mathrm{a}, 2, \mathrm{X}} \\
R^{2}=0.89\end{array}$ & $\begin{array}{c}2.61 \pm 2.02^{\mathrm{A}, \mathrm{a}, 2, \mathrm{X}} \\
R^{2}=0.98\end{array}$ & $\begin{array}{c}1.94 \pm 0.50^{\mathrm{A}, \mathrm{a}, 1, \mathrm{X}} \\
R^{2}=0.94\end{array}$ & $\begin{array}{c}2.25 \pm 0.96^{\mathrm{A}, \mathrm{a}, 1, \mathrm{X}} \\
R^{2}=0.96\end{array}$ & $\begin{array}{c}3.90 \pm 0.79^{\mathrm{A}, \mathrm{a}, 1, \mathrm{Y}} \\
R^{2}=0.81\end{array}$ & $\begin{array}{c}4.41 \pm 0.74^{\mathrm{A}, \mathrm{a}, 1, \mathrm{Y}} \\
R^{2}=0.88\end{array}$ & $\begin{array}{c}1.85 \pm 0.30^{\mathrm{A}, \mathrm{b}, 1, \mathrm{Y}} \\
R^{2}=0.83\end{array}$ & $\begin{array}{c}1.91 \pm 0.19^{\mathrm{A}, \mathrm{b}, 1, \mathrm{X}} \\
R^{2}=0.85\end{array}$ \\
\hline Abaxial & $\begin{array}{c}3.77 \pm 1.43^{\mathrm{A}, \mathrm{a}, 1,2, \mathrm{X}} \\
R^{2}=0.90\end{array}$ & $\begin{array}{c}4.38 \pm 1.35^{\mathrm{A}, \mathrm{a}, 1,2, \mathrm{X}} \\
R^{2}=0.9\end{array}$ & $\begin{array}{c}2.71 \pm 1.71^{\mathrm{A}, \mathrm{a}, 1, \mathrm{X}} \\
R^{2}=0.91\end{array}$ & $\begin{array}{c}2.24 \pm 0.48^{\mathrm{A}, \mathrm{b}, 1, \mathrm{X}} \\
R^{2}=0.83\end{array}$ & $\begin{array}{c}4.37 \pm 0.81^{\mathrm{A}, \mathrm{a}, 1, \mathrm{X}} \\
R^{2}=0.75\end{array}$ & $\begin{array}{c}4.78 \pm 2.16^{\mathrm{A}, \mathrm{a}, 1, \mathrm{X}} \\
R^{2}=0.73\end{array}$ & $\begin{array}{c}1.71 \pm 0.14^{\mathrm{A}, \mathrm{b}, 1 . \mathrm{X}} \\
R^{2}=0.85\end{array}$ & $\begin{array}{c}1.68 \pm 0.21^{\mathrm{A}, \mathrm{b}, 1,2, \mathrm{X}} \\
R^{2}=0.87\end{array}$ \\
\hline
\end{tabular}

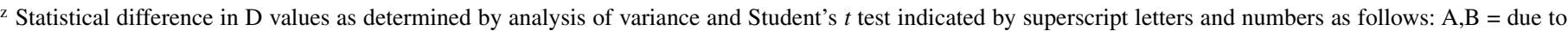
the impact of virus type on virus survival (compare across between MNV and TV for each spinach type); a,b = due to the impact of spinach leaf type (compare across with between semi-savoy and smooth spinach for each virus); 1,2 = due to the impact of inoculation location (compare down the column for effect of location on virus on specific leaf type with or without UV); and X,Y = due to the impact of additional UV (compare across between UV and optimal conditions for both virus and spinach type). 
behavior as well as the role of the plant. The leaf surface has been shown to provide unfavorable conditions for bacterial persistence and growth, including factors such as temperature fluctuation, UV radiation, desiccation, and limited nutrient availability $(3,21)$. Despite these adverse conditions, enteric bacterial pathogens have been shown to survive on leaf surfaces, and specialized cells of the leaf epidermis may provide increased protection for bacterial populations $(3,21)$. Understanding virus survival is important to consider when evaluating potential contamination from the environment to the table and in the design of good agricultural practices because the low infectious dose of these viruses means that a low level of contamination can pose a public health risk. The objective of this study was to evaluate the role of various factors on norovirus surrogate survival on spinach in conditions similar to preharvest field conditions. Factors tested include virus type, spinach cultivar, virus inoculation location on the spinach plant, and UVA/UVB exposure to mimic sunlight in the field.

MNV and TV were used as human norovirus surrogates in this study. Virus type was not a significant factor impacting virus survival on all locations of both spinach varieties because no significant difference in MNV and TV survival on spinach was observed under any condition. Also, no significant difference was observed between survival of MNV, TV, and human GII norovirus on semi-savoy whole plants. However, it must be taken into consideration that human GII norovirus persistence was detected via RT-qPCR, which may not be indicative of infectivity. For this reason, efforts to assess the factors that impact virus survival were focused on the human norovirus surrogates, where infectivity can be assessed. Our previous research indicated that MNV may be a better surrogate than TV for human noroviruses because of the greater stability observed, particularly in extreme $\mathrm{pH}$ solutions and persistence in tap water for 30 days at $4{ }^{\circ} \mathrm{C}$; however, in tap water at $20^{\circ} \mathrm{C}$, there was not a significant difference between MNV and TV survival (16). It is likely that one surrogate alone cannot fully mimic the characteristics of human norovirus stabili-
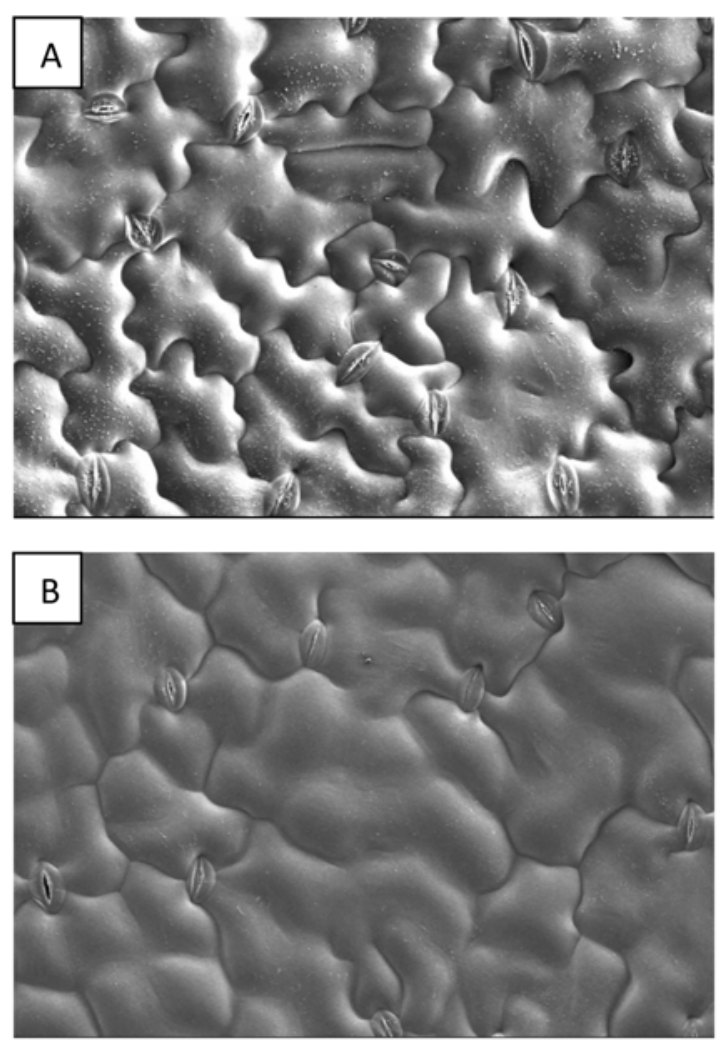

Fig. 2. Cryo-scanning electron microscopy images of semi-savoy spinach at $\times 250$ of $\mathbf{A}$, abaxial and $\mathbf{B}$, adaxial leaf surfaces. ties in the environment. In addition, there are many different genogroups and genotypes of human noroviruses that have slightly different environmental stabilities; therefore, several surrogates should be considered in the evaluation of environmental persistence.

Two cultivars of spinach were used in this study, a semi-savoy leaf and a smooth leaf. Semi-savoy leaves are used for freshmarket consumption whereas smooth-leaf varieties are typically used for processing. Results indicated that spinach type did significantly impact the survival of MNV and TV survival on spinach leaves under certain conditions (Table 1). In these conditions, $D$ values of virus survival were significantly higher on semi-savoy spinach leaves than smooth spinach leaves. These results coincide with previous research studies which have shown that the rougher or more irregular the surface of produce (i.e., semi-savoy type), the longer viruses are able to persist $(27,28)$. The surface texture and structure of vegetables play an important role in the attachment and survival of bacteria (28) as well as for viruses, as Stine et al. (27) observed the longest survival of Hepatitis A virus (HAV), Feline calicivirus, and bacteriophage PRD1 on cantaloupe as compared with lettuce and bell pepper. The authors believe that the lenticels, the netting on the rind, provides a variety of surfaces for pathogen attachment (27). Using microscopy, Gandhi et al. (14) observed recombinant norovirus-like particles binding to spinach and Romaine lettuce at specific locations that appeared to be depressions on the leaf, and to the veins. Although the spinach used in this study does not have the extreme irregular surface structures of cantaloupe, SEM images of both semi-savoy and smooth spinach plants (Fig. 2) show that the spinach leaves have depressions and a textured surface that could potentially serve as locations for viral entrapment and attachment. Topography of semi-savoy and smooth spinach varieties appears similar, which may explain the lack of difference in virus survival between the two spinach varieties. Additionally, it is well known that the leaf epidermis is covered with epicellular cuticular wax. This wax (cutin) may not play a role in the chemical attachment of these enteric viruses to the spinach because hydrophobic interactions were not observed to be involved in the attachment of viruses to lettuce (30); however, this waxy cuticle may allow for viral entrapment, as suggested by Stine et al. (27), whereby the more complex the wax structure, the greater the chance of entrapment (1).

Unlike the spinach leaf type, the virus inoculation location of either the whole plant, the adaxial (top of the leaf) surfaces, or the abaxial (underside of the leaf) surfaces were shown to play a statistically significant role in MNV and TV persistence. MNV and TV inoculated onto the abaxial leaves persisted longer than viruses on the adaxial surfaces of leaves (Table 1). This difference in virus survival on the leaf surfaces could be due to anatomical variations of the adaxial and abaxial surfaces of the plant. Stomata are generally found in higher densities on the abaxial side of leaves compared with the adaxial side (8), which could explain the higher survival of MNV and TV on the abaxial leaf surfaces of spinach. Although viruses have been observed to attach to the stomata of lettuce leaves $(9,32)$, viruses are considered to be non-living outside their host and cannot move to specific locations on the plant epidermis. Virus localization on or in stomata is likely an event of probability rather than preference and, if there are more stomata present on the abaxial surfaces of leaves, then there may be an increased likelihood for virus internalization into stomata on the abaxial surfaces. In addition to anatomical differences in the adaxial and abaxial leaf surfaces, it is likely that the greater physical protection from environmental factors such as UV exposure and desiccation may be afforded on the abaxial surfaces.

To assess the role of sunlight on the persistence of human norovirus surrogates, a UVA/UVB lamp was used in a controlled environment. The UV radiation that reaches the Earth from the 
sun is composed of UVA and a small component of UVB. UVA and UVB exposure varies depending upon regional location, and factors that affect this include latitude, cloud cover, season (sun elevation), altitude, ozone, and ground reflection (33). UV light has previously been found to be effective on reducing enteric pathogen populations on vegetables surfaces. Many studies have assessed the role of UV as a postharvest processing technology to reduce human enteric pathogens on produce; however, this loss of infectivity occurs from the application of UVC wavelengths (280 to $100 \mathrm{~nm}$ ) (13), and sunlight inactivation by the UVA/UVB wavelength range ( 400 to $280 \mathrm{~nm}$ ) may be different. In this study, a UVA/UVB lamp was used to mimic sunlight and was applied for $10 \mathrm{~h} /$ day. The effect of UVA/UVB significantly impacted D values for adaxial inoculated surfaces for MNV and TV on semisavoy leaves and for MNV on smooth leaves; however, the D values were higher after UVA/UVB exposure.

Virus survival on lettuce as compared with stainless-steel surfaces indicated that MNV inactivation was more rapid on lettuce than the steel disks, suggesting a potential role for lettuce cells on viral inactivation (10). This effect of the lettuce on virus persistence could also be affected by virus attachment and internalization into the lettuce $(14,31)$, whereby viruses are unable to be recovered from the lettuce surfaces. Another possibility for this lowered persistence on lettuce could be due to the fact that many plant leaves continuously secrete substances in small quantities that form the normal leachates on the leaf surface (5). These compounds may affect viral persistence and infectivity. More research will need to be conducted to ascertain whether compounds present in spinach may have any inhibitor effect on MNV and TV survival.

In addition to these enteric viruses being able to persist on spinach plants for up to 2 weeks, post-harvest studies on enteric virus survival on produce indicate that these pathogens are very persistent under storage conditions. Studies have shown that, if human enteric viruses were to survive in the preharvest environment, they will continue to survive in postharvest environments as well. Human noroviruses were detected on strawberry and lettuce after 7 days at refrigeration and room temperature (21). Hepatitis A virus (HAV), a human enteric viral pathogen, survived on lettuce with no reduction in titer after storage at refrigeration temperatures for up to 42 days (25). These studies indicate that any potential contamination of produce in the field would allow for virus survival at refrigeration temperatures for longer than the normal shelf life. Additionally, post-harvest treatments of spinach in a traditional chlorine wash were ineffective at reducing human norovirus titers, as reviewed by Hirneisen et al. (15). Understanding the behavior of enteric viruses on spinach leaves is useful for predictive microbiological assessment to consider the risks associated with certain growing conditions. This understanding of risk can be applied to produce grower guidelines and education.

\section{ACKNOWLEDGMENTS}

This project was funded by the National Integrated Food Safety Initiative of the United States Department of Agriculture NoroCORE grant number 1111-2011-0494.

\section{LITERATURE CITED}

1. Alum, A. 2001. Control of viral contamination of reclaimed irrigated vegetables by drip irrigation. Ph.D. thesis, University of Arizona, Tucson.

2. Baert, L., Mattison, K., Loisy-Hamon, F., Harlow, J., Martyres, A., Lebeau, B., Stals, A., Van Coillie, E., Herman, L., and Uyttendaele, M. 2011. Review: Norovirus prevalence in Belgian, Canadian and French fresh produce: A threat to human health? Int. J. Food Microbiol. 151:261269.

3. Barak, J. D., Kramer, L. C., and Hao, L. Y. 2011. Colonization of tomato plants by Salmonella enterica is cultivar dependent, and type 1 trichomes are preferred colonization sites. Appl. Environ. Microbiol. 77:498-504.

4. Beuchat, L. R. 2002. Ecological factors influencing survival and growth of human pathogens on raw fruits and vegetables. Microbes Infect. 4:413423.

5. Blakeman, J. P. 1973. The chemical environment of leaf surfaces with special reference to spore germination of pathogenic fungi. Pestic. Sci. 4:576-588.

6. Centers for Disease Control and Prevention (CDC). 2006. Ongoing multistate outbreak of Escherichia coli serotype O157:H7 infections associated with consumption of fresh spinach-United States, September 2006. Morbid. Mortal. Weekly Rep. 55:1045-1046.

7. DiCaprio, E., Ma, Y., Purgianto, A., Hughes, T., and Li, J. 2012. Internalization and dissemination of human norovirus and animal caliciviruses in hydroponically grown Romaine lettuce. Appl. Environ. Microbiol. 78:6143-6152.

8. Driscoll, S. P., Prins, A., Olmos, E., Kunert, K. J., and Foyer, C. H. 2006. Specification of adaxial and abaxial stomata, epidermal structure and photosynthesis to CO2 enrichment in maize leaves. J. Exp. Bot. 57:381390.

9. Esseili, M. A., Wang, Q. H., and Saif, L. J. 2012. Binding of human GII.4 norovirus virus-like particles to carbohydrates of Romaine lettuce leaf cell wall materials. Appl. Environ. Microbiol. 78:786-794.

10. Fallahi, S., and Mattison, K. 2011. Evaluation of murine norovirus persistence in environments relevant to food production and processing. J. Food Prot. 74:1847-1851.

11. Farkas, T., Cross, R.W., Hargitt, E., Lerche, N. W., Morrow, A. L., and Sestak, K. 2010. Genetic diversity and histo-blood group antigen interactions of rhesus enteric caliciviruses. J. Virol. 84:8617-8625.

12. Farkas, T., Sestak, K., Wei, C., and Jiang, X. 2008. Characterization of a rhesus monkey calicivirus representing a new genus of Caliciviridae. J. Virol. 82:5408-5416.

13. Fino, V. R., and Kniel, K. E. 2008. UV light inactivation of hepatitis A virus, Aichi virus, and feline calicivirus on strawberries, green onions, and lettuce. J. Food Prot. 71:908-913.

14. Gandhi, K. M., Mandrell, R. E., and Tian, P. 2010. Binding of virus-like particles of Norwalk virus to Romaine lettuce veins. Appl. Environ. Microbiol. 76:7997-8003.

15. Hirneisen, K. A., Black, E. P., Cascarino, J. L., Fino, V. R., Hoover, D. G., and Kniel, K. E. 2010. Viral inactivation in foods: A review of traditional and novel food-processing technologies. Comp. Rev. Food Sci. F. 9:3-20.

16. Hirneisen, K. A., and Kniel, K. E. 2012. Comparing human Norovirus surrogates: Murine norovirus and Tulane virus. J. Food Prot. 76:139-143.

17. Hirneisen, K. A., Markland, S. M., and Kniel, K. E. 2011. Ozone inactivation of norovirus surrogates on fresh produce. J. Food Prot. 74:836839.

18. Ingram, D. T., Patel, J., and Sharma, M. 2011. Effect of repeated irrigation with water containing varying levels of total organic carbon on the persistence of Escherichia coli O157:H7 on baby spinach. J. Food Prot. 74:709-717.

19. Koike, S. T., Cahn, M., Cantwell, M., Fennimore, S., LeStrange, M., Natwick, E., Smith, R. F., and Takele, E. 2011. Spinach production in California. http://anrcatalog.ucdavis.edu/pdf/7212.pdf

20. Kroupitski, Y., Golberg, D., Belausov, E., Pinto, R., Swartzberg, D., Granot, D., and Sela, S. 2009. Internalization of Salmonella enterica in leaves is induced by light and involves chemotaxis and penetration through open stomata. Appl. Environ. Microbiol. 75:6076-6086.

21. Mattison, K., Karthikeyan, K., Abebe, M., Malik, N., Sattar, S. A., Farber, J. M., and Bidawid, S. 2007. Survival of calicivirus in foods and on surfaces: Experiments with feline calicivirus as a surrogate for norovirus. J. Food Prot. 70:500-503.

22. Lewis, G. D., and Metcalf, T. G. 1988. Polyethylene-glycol precipitation for recovery of pathogenic viruses, including hepatitis-a virus and human rotavirus from oyster, water and sediment samples. Appl. Environ. Microbiol. 54:1983-1988.

23. Matthews, K. R. 2009. Leafy vegetables. Pages 165-189 in: The Produce Contamination Problem: Causes and Solutions. G. M. Sapers, E. B. Solomon, and K. R. Matthews, eds. Elsevier Inc., Burlington, VT.

24. Scallan, E., Hoekstra, R. M., Angulo, F. J., Tauxe, R. V., Widdowson, M. A., Roy, S. L., Jones, J. L., and Griffin, P. M. 2011. Foodborne illness acquired in the United States-major pathogens. Emerg. Infect. Dis. 17:715 .

25. Shieh, Y. C., Stewart, D. S., and Laird, D. T. 2009. Survival of Hepatitis A Virus in spinach during low temperature storage. J. Food Prot. 72:23902393.

26. Siebenga, J. J., Duizer, E., Koopmans, M. 2010. Norovirus Epidemiology. Pages 1-25 in: Caliciviruses: Molecular and Cellular Virology. G. S. Hansman, X. Jiang, and K. Y. Green, eds. Caister Academic Press, Norfolk, UK.

27. Stine, S. W., Song, I., Choi, C. Y., and Gerba, C. P. 2005. Effect of relative humidity on preharvest survival of bacterial and viral pathogens on the surface of cantaloupe, lettuce, and bell peppers. J. Food Prot. 68:13521358. 
28. Takeuchi, K., and Frank, J. F. 2001. Quantitative determination of the role of lettuce leaf structures in protecting Escherichia coli O157:H7 from chlorine disinfection. J. Food Prot. 64:147-151.

29. Teunis, P. F. M., Moe, C. L., Liu, P., Miller, S. E., Lindesmith, L., Baric, R. S., Le Pendu, J., and Calderon, R. L. 2008. Norwalk virus: How infectious is it? J. Med. Virol. 80:1468-1476.

30. Vega, E., Smith, J., Garland, J., Matos, A., and Pillai, S. D. 2005. Variability of virus attachment patterns to butterhead lettuce. J. Food Prot. 68:2112-2117.

31. Wei, J., Jin, Y., Sims, T., and Kniel, K. E. 2010. Manure- and biosolids- resident murine norovirus 1 attachment to and internalization by Romaine lettuce. Appl. Environ. Microbiol. 76:578-583.

32. Wobus, C. E., Thackray, L. B., and Virgin, H. W. 2006. Murine norovirus: A model system to study norovirus biology and pathogenesis. J. Virol. 80:5104-5112.

33. World Health Organization (WHO). 2002. Global Solar UV Index. http://www.who.int/uv/publications/en/GlobalUVI.pdf

34. Zheng, D. P., Ando, T., Fankhauser, R. L., Beard, R. S., Glass, R. I., and Monroe, S. S. 2006. Norovirus classification and proposed strain nomenclature. Virology 346:312-323. 